\title{
Effect of season of birth and genetic on post-partum anestrous period of Sudanese cattle
}

\author{
I Bushara \\ Department of Animal Production, Faculty of Natural Resources and Environmental Studies, j University of \\ Kordofan, Sudan \\ bushara3030@yahoo.com
}

\begin{abstract}
The experiment was conducted with cattle production in North Kordofan, which was closely monitored through a period of 365 days. Seven groups of cattle herders were selected randomly. The recently calved cows were monitored till next conception following post-partum ovarian activity using milk progesterone radioimmunoassay. Days to conception were taken as non-return to oestrus. Regression analyses were done for days to first progesterone rise and days to conception against season of calving and type of breed and correlation between them and body weight and milk yield. The results revealed that there was a wide variation in both days to first ovulation and days to conception. Dry season showed an adverse effect on fertility compared with the rainy season. Cows that had been calved during wet season showed delayed post-partum activity and days to conception with longest days to resumption of ovarian activity showed in dry season (87.66 \pm 52.25$)$. The interval to conception was longest in dry season (149.60 \pm 69.52 days) and lowest in wet season ( $113.00 \pm 73.80$ days) with higher conception rate. Regression analyses showed significant negative correlation obtained during the wet season between days to progesterone rise and body weight at calving, milk yield, Similary days to conception were found to decrease by 38 days for each increase of $1 \mathrm{~kg}$ milk yield at 60 and 90 days. Cross breeds, had longer days to ovulation and days to conception compared with local ones, but showed lower pregnancy rates. Local breed showed lowered days to reproductive parameters studied during wet season compared with dry season. Also local breed showed weak negative correlation between days 1st P4 rise and body weight at calving and Milk yield with decline in days. Significant negative correlation were obtained between days to conception and milk yield with corresponding decrease in days for each increase in $1 \mathrm{~kg}$ of milk yield. It could be concluded that, poor reproductive performance in cows kept under extensive traditional system was due to poor management practices, which ignored high-energy supplementation during late pregnancy and early lactation, especially during the dry season. Improving feeding strategies may greatly enhance reproductive performance of cows kept under extensive systems of management.
\end{abstract}

Keywords: cattle, reproductive, postpartum period, season, breed, grazing, traditional, system

\section{INTRODUCTION}

Cattle production in smallholder nomadic system is raised within pastoral in the western Sudan. The animals are grazed extensively on natural pastures in the open range, with minimal feed supplementation. The pastures are often limiting in quality and quantity. Thus the nutritional requirements of the cattle are barely met, resulting in poor body condition, weight loss, low milk yield and delays in the resumption of ovarian cycles after calving (Obese et al., 2010). Cattle population in Sudan is 41.56 million heads (MARF, 2009), playing pivotal roles in the economy, contributing $22 \%$ to total GDP, and providing livelihoods for many people, therefore contribute significantly to poverty reduction. Poor reproductive performance is a major problem on dairy farms throughout 
the Sudan and has been identified as the single most important problem in dairy herd management in Sudan, the best milk producing breeds in Sudan are Kenana and Butana and Baggara for meat production and their crosses with Frisian cow.

Generally milk production in Sudan tends to be highly seasonal, and most production occurs during the rainy seasons at the time of relatively plentiful grass and other forages. This availability of feed continues into the winter season when agricultural byproducts are available.

Serum progesterone levels are nearly undetectable until about 30 days post-partum (Taylor et al., 2003). Plasma progesterone concentrations were used to indicate when the cow had returned to normal estrous cycles and have been suggested as an important method for evaluating ovarian function objectively (Royal et al., 2000). Evidence of corpus luteum activity was defined as either plasma progesterone concentration greater than 1ng/ $\mathrm{ml}$ (Staples et al., 1990).

Reproductive performance is one of the major and most important factors determining the profitability of cattle herds, with the ideal goal to be achieved being one calf per cow per year (Rekwot et al., 2000). The interval from parturition to the restart of ovarian activity (the post-partum period) plays a pivotal role in cattle reproduction, with the postpartum anestrous being largely responsible for long intervals between parturition (Williams, 2005a). These lead to extended calving-to-conception intervals, which in turn cause long intercalving periods (Galina \& Arthur, 1989). The duration of post-partum has an important influence on reproductive performance (Peter et al., 2009). Early resumption of ovarian activity in post-partum cows is required to achieve calving to first service and conception interval of 55 and 85 respectively, which are necessary targets if 365- days calving interval is to be attained (Savio et al., 1990, Browning Jr. et al., 1996). The long postpartum interval observed in Bos indicus cattle is influenced by a large number of factors, including genetics (breed),nutrition, season of calving, milk yield, age/parity (Meikle et al., 2004), suckling, metabolic, reproduction health, uterine involution, presence of bull, body condition score and management practices (Jolly et al., 1995, Tomomi et al., 2008), the decline in dairy cow fertility has been attributed partly to unfavourable genetic correlations between milk yield and reproductive traits, and partly to increasing imbalance of nutrients leading to metabolic stress (Pryce et al. 2004). The effect of season on reproduction in cattle interacts in a complex manner with other environmental factors including breed and nutrition, body weight and level of milk production. In turn those factors affect the post-partum reproductive performance of the cow, so the study aimed to identify the effect of season of calving and breed on the time of initiate of ovarian activity of cow after calving.

\section{Material ANd Methods}

\section{Study area}

The present investigation focused on the reproductive performance of cows kept under sedentary husbandry system at peri-urban area around El Obeid city located at about $600 \mathrm{~km}$ west Khartoum capital (Latitude $11 \mathrm{o} 15$. and $16 \mathrm{o} 30 . \mathrm{N}$, Longitude $27 \mathrm{o}$ and $32 \mathrm{oE}$ ). It lies within a semi-arid area: temperatures ranges between $30.35 \mathrm{oC}$ $-40 \mathrm{oC}$ during the dry season (April to June). The rainy season extends from July to October. The dominant vegetation is a varying mixture of grasses and shrubs (Technoserve, 1987). The cattle farms are concentrated around city and are the main suppliers of milk to the inhabitants.

\section{Husbandry practices}

Seven sedentary cattle owner were randomly selected at different geographical sites around Elobied City. They were designated as farm A, B, C, D, E and G. Mature animals were kept in open enclosures made from local material or barbed wires, their sizes differed according to the number of the animal (Table1). 
American Research Journal of Agriculture (ARJA)

Table 1. Kind of breed and herd structure of the farms under study

\begin{tabular}{|c|c|c|c|c|c|c|c|}
\hline farms & Breeds & $\begin{array}{c}\text { Lactating } \\
\text { cows }\end{array}$ & Dry cow & Heifer & Calve & Bull & Total \\
\hline A & $\begin{array}{c}\text { Kenana, } \\
\text { Butana, DerElreeh*, } \\
\text { Crosses }\end{array}$ & 78 & 97 & 35 & 45 & 5 & 250 \\
\hline B & Kenana, Crosses & 72 & 21 & 114 & 28 & 3 & 238 \\
\hline C & DerElreeh & 15 & 9 & 15 & 7 & 2 & 48 \\
\hline D & DerElreeh & 10 & 7 & 12 & 5 & 1 & 35 \\
\hline E & DerElreeh & 8 & 11 & 15 & 8 & 1 & 42 \\
\hline F & DerElreeh & 18 & 12 & 16 & 8 & 1 & 46 \\
\hline G & DerElreeh & 22 & 18 & 27 & 10 & 10 & 62 \\
\hline
\end{tabular}

*local ecotype Zebu cattle

During the rainy season cattle spend around 6-9 h grazing during the day, moving over small distances (3-4 km). Surface water from natural ponds and catchment areas is their source of drinking water. During the dry season, more time is spent grazing $(8.10 \mathrm{~h})$ moving over longer distances $(7-8 \mathrm{~km})$ in search of good quality forage. They come back to the farms and then move another $1.2 \mathrm{~km}$ to find drinking water from deep wells in the city.

Calve were kept in separate sheds with roofs for protection against the sun. Milking was done twice day with calf at food, in the morning before animal's leaves for grazing and in the evening on their return. Calves were allowed to suckle for milk let down, and then were kept a part from their dams, but were allowed to graze during the day light hours not far from the farm. In some farms cows sometimes were milked one to enhance earlier conception and this called (Towgeeb), weaning was natural, insemination was also natural with bulls running freely with dams all times. During the dry season the animals were supplemented with crop residues and concentrates are offered before the afternoon milking. Approximately 0.75-1 kg of a concentrate ration is offered to each milking cow. The ingredients and percentages will depend on their availability and cost in the marked (Table 2). All farms depended on shafired animal attendants to look for their herds and on their experience for heath care and disease treatments. Vaccine against Rindderpest and Anthrax were done only when outbreak were expected. Prevailing disease were pneumonia internal and external parasites.

Table 2. Concentrate feed ingredients used in different farms

\begin{tabular}{|c|c|c|c|c|c|c|}
\hline farm & Sorghum & W B\% & G N C\% & GNH\% & Salt \% & other \\
\hline A & 50 & 20 & 29 & 0 & 1 & 0 \\
\hline B & 50 & 0 & $18-19$ & 30 & $1-2$ & 0 \\
\hline C & 60 & 9 & 30 & 0 & 1 & 0 \\
\hline D & 43 & 0 & 16 & 42 & 1 & 0 \\
\hline E & 40 & 0 & 0 & 0 & 0 & BR(60) \\
\hline F & 50 & 20 & 19 & 10 & 1 & 0 \\
\hline G & 60 & 10 & 29 & 0 & 1 & 0 \\
\hline
\end{tabular}

GNC, groundnut cake; GNH, groundnut hulls; BR, brewery residue (22\% crude protein, 1.1\% ether extract). 


\section{MEASUREMENTS}

\section{Milk Sampling}

Milk samples $(10 \mathrm{~mL})$ were collected into tubes containing sodium azide at weekly intervals beginning at 10 days from parturition and every week thereafter until the animal was confirmed pregnant by non-return to oestrus. Fat were remove from milk samples and then stored in a sealed plastic container at 20Co until assayed for progesterone using the solid-phase RIA system supplied by the Joint FAO/IAEA Division (Plazier, 1986). Progesterone concentrations greater than $1 \mathrm{nmol} / \mathrm{L}$ were considered to indicate cyclic ovaries.

\section{Body weight and milk yield}

Body weight was determined by measuring the heart girth using a weigh band. Milk yield were also recorded daily. The above parameters were measured at calving and at 30,60 and 90 days after calving.

\section{Statistical analysis}

Fertility parameters such as days to progesterone rise and days to conception were correlated with body weight at parturition, 30, 60 and 90 days from parturition, similar correlation were carried out with milk yield. The above correlation were also subjected to correlation by grouping cows according to breed (local - cross) and seasonal of parturition (wet- dry). Student t- test was done to compare days to ovulation or conception between dry or wet season and between local and cross breed, and also between dry and wet season for local and exotic breed separately using the model procedure of Statistical Analytical System (SAS, 1990).

\section{RESULTS}

\section{Effect of season on first progesterone rise and days to conception}

The season of calve appeared to have an effect on the interval from calving to first ovulation and the number of days to conception. There was significantly $(\mathrm{P}<0.05)$ early resumption of ovarian activity during the wet season (July to October) compared to dry months (April to June) which was longer. The interval from calving to conception were significantly $(\mathrm{P}<0.05)$ longer during the dry season compared to the wet season. Conception rate was better in the wet season (Table 3).

Table 3. Efect of season of calving on days to first progestrone rise and days to conception

\begin{tabular}{|c|c|c|c|}
\hline Season & Days to ovulation & Days to conception & Pregnancy rate \\
\hline Dry & $87.66 \pm 52.25 \mathrm{a}$ & $149.60 \pm 69.52 \mathrm{a}$ & 90.1 \\
\hline Wet & $72.17 \pm 43.45 \mathrm{~b}$ & $113.00 \pm 73.80 \mathrm{~b}$ & 96.2 \\
\hline
\end{tabular}

Values with the same column bearing different superscript vary significantly at $P<0.05$

There was significant negative correlation obtained during the wet season between days to $\mathrm{P} 4$ rise and body weight at calving, milk yield at 30, 60 and 90 day from calving $(r=-0.63, P<0.001) \mathrm{M} 30(\mathrm{r}=-0.42, \mathrm{P}<0.045)$, $\mathrm{M} 60(\mathrm{r}=-0.62, \mathrm{P}<0.002)$ and M90 $(\mathrm{r}=-0.64, \mathrm{P}<0.001)$, with corresponding reductions in days to $\mathrm{P} 4$ rise of $0.48,41.10,36.20$ and 30.92 (Table 2). Similary days to conception were found to decrease by 38 days for each increase of $1 \mathrm{~kg}$ milk yield at 60 and 90 days (Table 4). 
American Research Journal of Agriculture (ARJA)

Table 4. Regression analysis for days to first progesterone rise and days to conception on season of calving

\begin{tabular}{|c|c|c|c|}
\hline \multicolumn{4}{|c|}{ days to first progesterone rise } \\
\hline Regression equation & Probability & $\mathrm{R} 2$ & $\mathrm{R}$ \\
\hline$Y=206.89-0.48$ (BWT at calving) & $<0.004$ & 0.39 & -0.63 \\
\hline$Y=195.55-41.12$ (My at 30) & $<0.045$ & 0.18 & -0.42 \\
\hline$Y=207.39-36.2($ My at 60$)$ & $<0.002$ & 0.38 & -0.62 \\
\hline$Y=187.13-30.92($ My at 90$)$ & $<0.001$ & 0.41 & -0.64 \\
\hline \multicolumn{4}{|c|}{ days to conception } \\
\hline$Y=268.93-38.2($ My at 60$)$ & $<0.02$ & 0.23 & -0.48 \\
\hline$Y=268.72-38.32($ My at 90$)$ & $<0.004$ & 0.33 & -0.58 \\
\hline
\end{tabular}

$Y=$ dependent variable (days to conception)

$R 2=$ Coefficient of determination

$R=$ Coefficient of correlation

$\left.\begin{array}{l}\text { BWT=Body weight } \\ \text { My=milk yield }\end{array}\right\}$ Independent variables

At calving, 30, 60 and 90 days from calving

\section{Effect of breed on first progesterone rise and days to conception}

When the effect of breed was tested for post-partum ovarian cyclicity or days to conception, the cross breeds took not significantly $(\mathrm{P}<0.05)$ more time to return to cyclicity compared to the local animals. Days to conception was also longer $(\mathrm{P}<0.05)$ in the cross breeds. Conception rate was higher $(\mathrm{P}<0.05)$ with the local breed $($ Table 5$)$.

Table 5. Efect of breed on days to ovulation and days to conception

\begin{tabular}{|c|c|c|c|}
\hline Breeds & Days to conception & Days to conception & Pregnancy rate \\
\hline Local & $79.9 \pm 48.86$ & $133.12 \pm 59.46$ & 87.7 \\
\hline Cross & $122.0 \pm 52.2$ & $267.00 \pm 25.5$ & 6.8 \\
\hline
\end{tabular}

The effect of dry season on reproductive parameters of local breed did not showed significant $(\mathrm{P}<0.05)$ effect; it took more time to return to cyclicity compared to those calved at wet season. Days to conception was also longer $(\mathrm{P}<0.05)$ in the dry season compared to those calved at wet season (Table 6).

Table 6. Efect of season on local breed on days to ovulation and days to conception

\begin{tabular}{|c|c|c|}
\hline Season & Days to 1st p4 rise & Days to conception \\
\hline Dry & $87.09 \pm 52.73$ & $136.41 \pm 67.20$ \\
\hline Wet & $69.41 \pm 42.35$ & $107.77 \pm 71.04$ \\
\hline
\end{tabular}

according to breed, the local breed showed weak negative correlation between days 1st P4 rise and body weight at calving, Milk yield at 60 and 90 days with decline in days of 0.27, 11.3, 24.3 and 14.2 respectively (Table 7). Significant negative correlation were obtained between days to conception and milk yield at 60 days $(\mathrm{r}=-0.46$, $\mathrm{P}<0.0007)$ and M90 ( $\mathrm{r}=-0.47, \mathrm{P}<0.0004)$ with corresponding decrease of 40.3 and 26.7 days for each increase in $1 \mathrm{~kg}$ of milk yield (Table 7). 
American Research Journal of Agriculture (ARJA)

Table 7. Regression analysis for days to first progesterone rise and days to conception on local and cross breed

\begin{tabular}{|c|c|c|c|}
\hline \multicolumn{4}{|c|}{ days to first progesterone rise } \\
\hline Regression equation & Probability & $\mathrm{R} 2$ & $\mathrm{R}$ \\
\hline $\mathrm{Y}=161.51-0.27$ (BWT at calving) & $<0.037$ & 0.06 & -0.25 \\
\hline $\mathrm{Y}=171.54-24.3$ (My at 60) & $<0.005$ & 0.11 & -0.34 \\
\hline $\mathrm{Y}=139.85-14.17$ (My at 90) & $<0.011$ & 0.09 & -0.31 \\
\hline \multicolumn{4}{|c|}{ days to conception } \\
\hline $\mathrm{Y}=285.09-40.29$ (My at 60) & $<0.0007$ & 0.21 & -0.46 \\
\hline $\mathrm{Y}=245.95-26.66$ (My at 90) & $<0.0004$ & 0.22 & -0.47 \\
\hline
\end{tabular}

$Y=$ dependent variable (days to conception)

$R 2=$ Coefficient of determination

$R=$ Coefficient of correlation

$B W T=$ Body weight

My= Milk yield

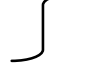

Independent variables

At calving, 60 and 90 days from calving

\section{DisCUSSION}

Tropical cattle breeds generally have prolonged anoestrous (parturition to first observed oestrus or first service) periods. Decreasing conception rates and delayed resumption of ovarian cyclicity postpartum will extend calving to conception intervals, disrupt seasonal calving and ultimately increase the proportion of cows culled for infertility.

In this work all cattle showed long period from calving to all reproductive parameters studied. Season of calving was found to have highly significant effect on reproductive parameters, there was early resumption of ovarian activity $(\mathrm{P}<0.05)$ during the wet season (July to October) compared to dry months (April to June) which was longer. The interval from calving to conception were significantly $(\mathrm{P}<0.05)$ longer during the dry season compared to the wet season. This result is online with Opsomer et al., (2000), Petersson (2007) and Hammoud et al., (2010). When cows calving during dry season and did not received no supplementation during their pre-partum period and hence were likely to calve in poor condition, they may faced lack of nutrient to fulfill their requirement for high milk yielding. Negative energy balance, common in early lactation, this is due to low intake capacity, which makes the energy input lower than the demands for production and maintenance (NRC, 2001and Butler, 2003).

when animal in negative energy balance that cannot meet the need of early lactation production. Therefore, cows end up using their body reserves to meet the energy requirements for lactation (Choumei et al., 2006) and dramatically appear on body weight and condition score losses than prolonged the length of the post partum anovulatory period and reduced conception rate (Meikle et al., 2004 and Hammoud et al..2010). During the rainy season animals were allowed to graze the native pasture with high quality and quantity, which fulfills the requirement for production. So this high level of feeding after calving tends to shorten the interval from first breeding to conception and thus reduce calving interval (Pryce et al., 2000 and Melendez and Pinedo, 2007).

Days to conception were significantly longer and conception rates were significantly lower in the dry season 
compared to the wet season, which could be attributed to nutrition and ambient temperature, the poor nutritive value of the pasture in quality and quantity of the pasture and extra energy expenditure during grazing. Although concentrates offered by farmers were of good quality, they were not offered in adequate quantities as they were sometimes given every other day due to their high cost. This could place cows in negative energy balance and thereby affecting the calving to conception interval and conception rates. Similar findings were reported by other workers (Thatcher et al, 1986 and Jagdeep etal 2015). The ambient temperatures that exceeded to 40Co, and this is agree with finding of Peters (1991) who reported that the inhibitory effect of thermal stress resulting in reduced hypothalamic GnRH secretion, lack of LH secretion and consequently affecting ovarian follicle development.

The effect of bodyweight change as influence reproductive performance were appear in this study, where days to first progesterone rise were decrease by 48 days for each increase of $1 \mathrm{~kg}$ body weight, same result reported by Robinson (1990). Furthermore, it has been shown that responses to pre-partum body weight change may depend on body condition score at parturition, since pregnancy rate of cows in good body condition at calving is affected little by minimal body weight changes either before or after parturition. This result in on line with Rakestraw et al, (1986) and Petersson (2007) who reported that a decrease of more than $50 \mathrm{~kg}$ in body weight during the first 8 weeks of lactation had an increased risk of delayed cyclicity profiles. Taylor et al. (2003) reported that cows with the lowest body weight and the greatest losses in body condition score after calving had a long period of negative energy balance will delayed cyclicity.

Effect of milk yielding on reproductive performance was significantly observed in this study. Where days to first progesterone rise and days to conception were found to decrease by 12, 36, 30 and 38 days for each increase of $1 \mathrm{~kg}$ milk production, this is agree with reported of Petersson (2007) who said that increased energy corrected milk yield of 1 SD (about $420 \mathrm{~kg}$ ) at the first 60 days in milk were associated with increased interval from calving to commencement of luteal activity of by 3.7 days and increased interval from calving to first ovulatory oestrus of by 6.3 days. The negative correlation between milk yield and fertility parameters could be related to body weight and body condition score which were affected milk production at different stages of lactation and rate of mobilization of body fat reserves which contributed to fix milk production (Dominguez et al, 1996).

Effect of breed of cows on days to first progesterone rise and days conception were not significantly affected since cross breed hand longer days and lowered conception rates compared with local breed, this result the genetic group may influence the reproductive performance of cows by changing the length of pregnancy and postpartum return of ovarian activity, similar results were obtained by Berglund et al., (1989) and Wiltbank et al (2006).

De Vries and Veerkamp (2000) reported a positive relationship between milk yield and time to first oestrus or ovulation as affected by type of breed.. In this study there is negative correlation between days to first ovulation and milk yield, whereas increase of $1 \mathrm{~kg}$ of milk yield increase days to first ovulation by 24 and 14 days, also days to conception increase to 29 and 66 days, this result similar to Royal et al (2002), Roche (2006) and Veerkamp and Beerda (2007)who reported that the high yielding breed seemed to have longer ovarian activity interval after calving compared with other cows. Heat stress seemed to impose an adverse effects on the cross breeds as reflected on longer days to conception and lower conception rates.

Prolonged post-partum anoestrus in lactating cows under extensive systems may reflect an adaptive mechanism, which prevents reconception until nutritional, or other environmental conditions become favorable for reproduction. Furthermore, it has been shown that during the wet season significant negative correlation existed between body weight at calving and post-partum resumption to ovarian activity. 


\section{CONCLUSION}

Management of post-partum anoestrus under extensive tropical environments should focus on the conservation of body weight and body condition score by strategic and adequate supplementation during late pregnancy and early lactation and hence reduce days to conception.

\section{REFERENCES}

Berglund, B., Danell, B., Janson, L., Larsson, K., 1989. Relationships between production traits and reproductive performance in dairy cattle. Acta Agric. Scand. 39, 169-179.

Browning J.R. R., Leite - Browning, M.L., Lewis, A.W. 1996. Sire breed of calf influencesperipartumendocrineprofilesand postpartum anestrus in Brahman cows. Domestical Animal Endocrinology, v.13, n.6, p.511-517.

Butler, W.R. 2003 Energy balance relationships with follicular development, ovulation and fertility in postpartum dairy cows. Livestock Production Science 83 211-218.

Choumei, Y.; Kahi, A. K. and Hirooka, H. 2006. Fit of ood's function to weekly records of milk yield, total digestible nutrient intake and body weight changes in early lactation of multiparous Holstein cows in Japan. Livestock Science 104:156-164.

De Vries, M. J. and Veerkamp, R. F. 2000. Energy balance of dairy cattle in relation to milk production variables and fertility. Journal of Dairy Science 83:62-69.

Dominguez, C., Martinez. N., Labrader, C., Risso, J. and Lopez, S. 1996. Effect of strategic feed supplementation with multinutrient blocks on productive and reproductive performance in dual-purpose cows. In: development of feed supplementation strategies for improving ruminant productivity on small holder farms in Latin America through the use of immunoassay techniques.Vienna.1993.P.97-105.

Galina C.S. \& Arthur G.H., 1989a, Review of cattle reproduction in the tropics. 2. Parturition and calving intervals. Anim. Breed. Abst. 57, 679- 686.

Hammoud, M.H., S. Z. El-Zarkouny , E. Z. M. Oudah.2010. Effect of sire, age at first calving, season and year of calving and parity on reproductive performance of Friesian cows under semiarid conditions in Egypt Archiva Zootechnica 13:1, 60-82.

Jagdeep Kumar, Y. P. Singh, Sushil Kumar, Rajbir Singh, Ravinder Kumar and Pradeep Kumar. 2015. Genetic analysis of reproductive performance of Frieswal cattle at Military Farm, Ambala. Veterinary World 8(8): 1032-1037.

Jolly, P.D.; McDougall, S.; Fitzpatrick, L.A. 1995. Physiological effects of undernutrition on postpartum anoestrus in cows. Journal Reproduction Fertility (Supl.), v.49, p.477-492.

Meikle, A., Kulcsar, M., Chilliard, Y., Febel, H., Delavaud, C., Cavestany, D. and Chilibroste, P. (2004). Effects of parity and body condition at parturition on endocrine and reproductive parameters of the cow. Reproduction 127: 727 - 73.

Melendez, P. and Pinedo, P. (2007). The Association Between Reproductive Performance and Milk Yield in Chilean Holstein Cattle. J. Dairy Sci., 90:184-192.

NRC - National Research Council. 2001. Nutrient requirements of dairy cattle. 7th rev. ed. National Academy Press, Washington, DC. 
Obese, F.Y., Dafour-Oduro, K.A., Gomda, Y. \& Bekoe, E., 2010. Reproductive performance following artificial insemination in Sanga and Crossbred (Friesian x Sanga) cows in the Accra Plains of Ghana. In: Sustainable Improvement of Animal Production and Health. Eds: Odongo, N.E., Garcia, M. \& Viljoen, G.J., IAEA Publication, Vienna, Austria. pp. 201-203.

Opsomer, G., Gröhn, Y.T., Hertl, J., Coryn, M., Deluyker, H. \& de Kruif, A. 2000. Risk factors for post partum ovarian dysfunction in high producing dairy cows in Belgium: a field study. Theriogenology 53, 841-857.

Peter, A. R.1991. "Recent techniques for improving reproductive efficiency of livestock", Isotope and related techniques in animal production and health, International Atomic Energy Agency, Vienna: 423-436.

Peter, A.T., Vos Plam and Ambrose DJ (2009). Postpartum in dairy cow. Theriogenology., 71: 1333-1342.

Petersson , Karl-Johan. 2007 Milk Progesterone as a Tool to Improve Fertility in Dairy Cows. Doctoral thesis Swedish University of Agricultural Sciences Uppsala . Faculty of Veterinary Medicine and Animal Science Department of Animal Breeding and Genetics Uppsala.

Plazier, J.C.B.1986. Validation of FAO/IAEA RIA KIT for the measurement of progesterone in skin milks blood plasma. In: Improving the productivity of indigenous African livestock, IAEA-TECDOC-708 (1993): 151-156.

Pryce, J.E., Royal, M.D., Garnsworthy, P.C. \& Mao, I.L. 2004 Fertility in the high producing dairy cow. Livestock Production Science 86 125-135.

Pryce, J.E., Coffey, M.P. and Brotherstone, S. (2000). The genetic relationship between calving interval, body condition score and linear type and management traits in registered Holsteins. Journal of Dairy Science 83 (11): $2666-2670$.

Rakestraw, J., Lusby, K.S., Wettlemann, R.P., Wagner, J.J.1986. Post partum weight and body condition loss and performance of fall-calving cows, Theriogenology 26: 461-473.

Rekwot PI, Ogwu EO, Oyedipe and Sekoni Vo (2000). The role of pheromones and Biostimulation in animal reproduction. Anim. Reprod. Sci., 65: 157-170.

Robinson,J.J. 1990.Nutrition in the reproduction of farm animals.Nutrition Research Reviews, 3:253-276.

Roche, J. R. 2006. The effect of nutritional management of the dairy cow on reproductive efficiency. Animal Reproduction Science 96:282-296.

Royal, M.D., Flint, A.P.F., Woolliams, J.A., 2002. Genetic and phenotypic relationships among endocrine and traditional fertility traits and production traits in Holstein-Friesian dairy cows. J. Dairy Sci. 85, 958-967. SAS, 1990. User's guide; version 6-4th ed.SAS Inst. I.n. c., Cary, NC.

Savio JD, Boland MP, Hynes N and Rochet JF (1990). Resumption of follicular activity in the early post-partum period of dairy cows. J. Reprod. Fert., 88: 569-579.

Staples CR, Thatcher WW and Clark JH (1990). Relation between ovarian activity and energy status during the early postpartum period of high producing dairy cows. J. dairy sci., 73: 938-947.

Taylor, V.J., Beever, D.E., Bryant, M.J. \& Wathes, D.C. 2003. Metabolic profiles and progesterone cycles in first lactation dairy cows. Theriogenology 59, 1661-1677.

Technoserve.1987. Credit component baseline survey. Technoserve Inc., Agricultural Bank of Sudan and US Agency for Agricultural Development, Elobied, Sudan.204 
Thatcher, W.W., Coltur, R.J., Beedee, D.K., Willcox, C.J.1986. Interaction of environment and reproductive processes in cattle, Nuclear and related techniques for improving productivity of indigenous animals in harsh environments, International Atomic Energy Agency, Vienna : 61-72.

Tomomi TA, Mayumi O, Shohei U, Saya K, Takenobu K, Seungjoon, Hideo K (2008). Influence of parity on follicular dynamics and resumption of ovarian cycle in postpartum dairy cows. Anim. Reprod. Sci, 108: 134- 143.

Veerkamp, R.F., Beerda, B.2007. Genetics and genomics to improve fertility in high producing dairy cows. Theriogenology, 68:S266-S273.

Willams, G.L.2005. Physiology and management of the postpartum suckled cow for controlled breeding programs. In: WILLIAMS, G.L.; FORREST, D.W. (Eds.) Proceedings, applied reproductive strategies in beef cattle. College Station: Texas A\&M University,p.184-196.

Wiltbank, M., Lopez, H., Sartori, R., Sangsritavong, S. \& Gümen, A. 2006. Changes in reproductive physiology of lactating dairy cows due to elevated steroid metabolism. Theriogenology 65, 17-29.

Citation: I Bushara, "Effect of season of birth and genetic on post-partum anestrous period of Sudanese cattle". American Research Journal of Agriculture, Volume 2; pp:1-10

Copyright (c) 2016 I Bushara, This is an open access article distributed under the Creative Commons Attribution License, which permits unrestricted use, distribution, and reproduction in any medium, provided the original work is properly cited. 